\title{
Genetic Variability and Divergence Studies for Gall Midge Resistance and Yield Components in Rice (Oryza sativa L.)
}

\author{
B. Srinivas*, Y. Chandramohan, S. Thippeswamy and D. Padmaja
}

Division of Rice Research Scheme, Regional Agricultural Research Station, Professor Jayashankar Telangana State Agricultural University, Polasa, Jagtial, Telangana State (505 529), India

Article History

Manuscript No. AR1433b

Received in $18^{\text {th }}$ August, 2015

Received in revised form $15^{\text {th }}$ January, 2016

Accepted in final form $5^{\text {th }}$ February, 2016

\section{Correspondence to}

*E-mail: srinu.bdd@gmail.com

\section{Keywords}

Rice, yield, gall midge resistance, heritability, genetic divergence

\begin{abstract}
Eighteen rice genotypes were evaluated for studying genetic parameters and genetic divergence for yield contributing characters and gall midge resistance at Regional Agricultural Research Station, Jagtial, Telangana. Analysis of variance revealed the presence of significant variability in experimental material for all the traits under study. Heritability estimates and genetic advance values indicated that percent of galls, effective bearing tillers plant ${ }^{-1}, 1000$ grain weight and number of grains panicle ${ }^{-1}$ were predominantly governed by additive genes which could be improved through proper selection in desirable direction, whereas, non additive genes played dominant role in the inheritance of days to $50 \%$ flowering, plant height and panicle length which could be improved through heterosis breeding. Mahalanobis $\mathrm{D}^{2}$ analysis distributed 18 genotypes into three clusters with cluster I containing maximum number of genotypes (14). Maximum inter cluster distance (10.48) was observed between cluster II and cluster III indicating wider genetic diversity, hence, crosses involving parents belonging to these clusters likely to produce wide variability and transgressive segregants with high heterotic effects. Genotypes JGL 19607, JGL 21820, JGL 3844 (cluster II) and JGL 23745 (cluster III) exhibited least gall midge incidence which could be utilized as parents in developing gall midge resistance genotypes. 1000 grain weight and days to $50 \%$ flowering were contributed maximum $(75.16 \%)$ to the total divergence which could be given due importance during hybridization and selection in segregating populations.
\end{abstract}

\section{Introduction}

Rice is the most important cereal in the world and serves as essential food grain in the diets of hundreds of millions of Asians, Africans and Latin Americans living in the tropics and sub tropics. However, the rate of increasing rice production is slowing down due to various abiotic factors like climate, soil, nutrient management practices etc. and biotic factors like pest and disease prevalence. The Asian gall midge (Orseolia oryzae) incidence is common in India and regions like northern Telangana, Vidharba (Maharastra), Sambalpur (Orissa) and coastal Karnataka are endemic to this pest where moderate to severe yield losses occurs (Krishnaiah and Varma, 2011). In India gall midge damage causes an average annual yield loss of about 477 thousand $t$ of grain or $0.8 \%$ of the total production amounting to US\$ 80 million (Bentur et al., 2003). Over the period in India, number of high yielding varieties with gall midge resistant has been developed in public and private sector. But the emergence of new virulent biotypes of gall midge in popular rice varieties is capable of overcoming resistance and this is a cause for concern (Lingaraj et al., 2008). Spreading of the new virulent biotypes to new areas draws the attention of entomologists and breeders to keep continuous monitoring for new biotypes and breeding for gall midge resistant varieties to avoid future out breaks. Gall midge being a entophytic, breeding rice varieties has been a viable and ecologically acceptable approach to manage this pest (Henrichs and Pathak, 1981). Apart from the resistance to various pest and diseases, there is a need to develop varieties with improved yield and other desirable agronomic traits. The need for improving productivity by exploiting available variability in the rice germplasm has been long left. Knowledge on the nature and magnitude of genetic variation present in the available germplasm for various quantitative characters like yield and its components is essential for effective genetic improvement. A critical analysis of genetic variability is a pre- 
requisite for initiating any crop improvement programme and for adopting of appropriate selection techniques. Variability present in germplasm for various agronomic traits is the key component of breeding programmes for broadening the genetic base. Once genetic variability is ascertained, crop improvement through appropriate selection can proceed. The available variability in a population can be partitioned into heritable and non heritable parts with the aid of genetic parameters such as coefficient of variation, heritability and genetic advance (Miller et al., 1958). Heritability estimates provides the information about the proportion of variability transmitted to the subsequent generations. Genetic advance provides information on expected genetic gain resulting from selection of superior genotypes. Variability through various genetic parameters in rice populations have been studied by several workers like Yaqoob et al. (2012); Kumar et al. (2014). Selection of desirable segregants from segregating populations could be achieved through the inclusion of most divergent parents in breeding programme. The pace and magnitude of genetic improvement are generally dependent on the amount of genetic diversity present in a population (Kumbhar et al., 2015). Genetic divergence determines the inherent potential of a cross for hybrid vigour and frequency of desirable recombinants in subsequent generations. Murthy and Arunachalan (1966) emphasized the importance of genetic diversity existing in the germplasm. Several workers viz., Roy and Panwar (1993); Bose and Pradhan (2005); Ramya and Kumar (2008); Ramanjaneyulu et al. (2014) used D ${ }^{2}$ statistics for estimation of genetic divergence in the populations. Therefore, knowledge about the genetic diversity present in the germplasm for different yield traits and pest tolerance is the key information for any breeder for initiation of breeding programme for crop improvement. In this context, present study was undertaken to study the variability present in the experimental material for various yield parameters and identifying the high yielding and gall midge resistant genotypes based on diversity analysis.

\section{Materials and Methods}

The experimental material for present study was comprised of 18 rice cultivars (Table 1) developed through pedigree method of breeding at Regional Agricultural Research Station (RARS), Jagtial, Telangana, India. The material was laid out in a randomized block design during kharif, 2014 at RARS, Jagtial. 25 days age old seedlings of each entry was transplanted in $10.44 \mathrm{~m}^{2}$ area with three replications by adopting spacing of $15 \times 15 \mathrm{~cm}^{2}$ between the rows and within the row. Two seedlings were planted at each hill. The crop was grown with the application of N, P and K fertilizer@100, 50 and $40 \mathrm{~kg}$ ha $^{-1}$ respectively. All recommended package of practices and need based plant protection measures were followed to raise a good crop. Data were recorded at maturity on 10 random plants for each entry in each replication for effective bearing tillers plant $^{-1}$, plant height $(\mathrm{cm})$, panicle length $(\mathrm{cm})$ and number of grains panicle ${ }^{-1}$. Days to $50 \%$ flowering and grain yield ha-1 were recorded on whole plot basis, whereas, random sample was used to estimate 1000 grain weight $(\mathrm{g})$ for each entry in each replication. Northern Telangana zone is the hot spot for gall midge incidence where natural screening of this pest could result in identification of resistance genotypes. Moreover, as gall midge incidence is severe in late sown conditions, the experimental material was sown late for obtaining more incidence, and the data onpercent of galls was recorded as per IRRI, SES (2002). The mean data after computing for each trait was subjected to analysis of variance (Panse and Sukhatme, 1985), genotypic and phenotypic coefficients of variation (Falconer, 1981), heritability $\left(\mathrm{h}^{2}\right)$ in the broad sense (Allard, 1960) and genetic advance (Burton, 1952) following standard procedures. The analysis of genetic divergence was done using Mahalanobis (1936) $\mathrm{D}^{2}$ statistics. Grouping of genotypes into clusters was carried out following Tocher's method (Rao,

Table 1: List of genotypes studied along with the pedigree and grain type

\begin{tabular}{|c|c|c|c|}
\hline $\begin{array}{l}\text { Sl. } \\
\text { no. }\end{array}$ & Designation & Pedigree & $\begin{array}{l}\text { Grain } \\
\text { type }\end{array}$ \\
\hline 1. & JGL 19607 & JGL $11470 \times$ T 1477 & SS \\
\hline 2. & JGL 20122 & MTU 1010×JGL 11727 & LS \\
\hline 3. & JGL 20668 & JGL $11727 \times$ JGL 11470 & LS \\
\hline 4. & JGL 20776 & MTU 1010×JGL 13595 & MS \\
\hline 5. & JGL 20777 & MTU 1010×JGL 13595 & MS \\
\hline 6. & JGL 21002 & MTU 1010×JGL 11727 & LS \\
\hline 7. & JGL 21005 & MTU 1010×JGL 11727 & LS \\
\hline 8. & JGL 21078 & MTU 1010×JGL 11470 & LS \\
\hline 9. & JGL 21794 & MTU 1010×JGL 11118 & LS \\
\hline 10. & JGL 21820 & JGL $13595 \times$ JGL 11470 & MS \\
\hline 11. & JGL 21828 & JGL $13595 \times$ JGL 11470 & MS \\
\hline 12. & JGL 21851 & JGL 11118×JGL 11727 & LS \\
\hline 13. & JGL 21868 & MTU 1010×JGL 11727 & LS \\
\hline 14. & JGL 21883 & MTU 1010×JGL 11470 & LS \\
\hline 15. & JGL 23745 & JGL $11727 \times$ VD 82 & LB \\
\hline 16. & JGL 3844 & $\begin{array}{l}\text { Released variety from RARS, } \\
\text { Jagtial }\end{array}$ & MS \\
\hline 17. & JGL 11118 & $\begin{array}{l}\text { Released variety from RARS, } \\
\text { Jagtial }\end{array}$ & MS \\
\hline 18. & JGL 18047 & $\begin{array}{l}\text { Released variety from RARS, } \\
\text { Jagtial }\end{array}$ & LS \\
\hline
\end{tabular}

LS: Long slender; MS: Medium slender; LB: Long bold; SS: Short slender 
1952). Intra and inter cluster distances and mean performances of clusters for all the traits were also computed.

\section{Results and Discussion}

Analysis of variance (Table 2). revealed significant differences among the genotypes for all the characters studied indicating the presence of considerable amount of variability among the genotypes for percent of galls and yield parameters. Significant genetic variation in various component characters might be effective. Mean data (Table 3). on various characters revealed that JGL 21794 and JGL 18047 recorded least maturity durations, whereas, JGL 3844 and JGL 19607 recorded highest flowering durations among all the genotypes. JGL 21851 (26.87 $\mathrm{cm})$ and JGL $23745(26.27 \mathrm{~cm})$ were characterized by bearing long panicles. Long bold grain genotype JGL 23745 exhibited highest test weight $(30.83 \mathrm{~g})$ and least was recorded for JGL 20668 (13.57 g), JGL 21828 (14.13 g) and JGL 19607 (14.77 g). JGL 21820 and JGL 19607 which have medium slender and short slender grain types respectively recorded highest number of grains panicle ${ }^{-1}$, whereas, JGL 21005 recorded least.Highest

\begin{tabular}{lccccccccc}
\hline \multicolumn{2}{l}{ Table 2: Mean squares corresponding to various sources of variation for 8 characters in rice } \\
\hline $\begin{array}{l}\text { Source } \\
\text { of variation }\end{array}$ & $\begin{array}{c}\text { Degrees } \\
\text { of freedom }\end{array}$ & $\begin{array}{c}\text { Days to } 50 \% \\
\text { flowering }\end{array}$ & $\begin{array}{c}\text { Effective } \\
\text { bearing tillers } \\
\text { plant }{ }^{-1}\end{array}$ & $\begin{array}{c}\text { Plant } \\
\text { height } \\
(\mathrm{cm})\end{array}$ & $\begin{array}{c}\text { Panicle } \\
\text { length } \\
(\mathrm{cm})\end{array}$ & $\begin{array}{c}1000 \text { grain } \\
\text { weight }(\mathrm{g})\end{array}$ & $\begin{array}{c}\text { Number } \\
\text { of grains } \\
\text { panicle }^{-1}\end{array}$ & $\begin{array}{c}\text { Percent } \\
\text { of galls } \\
(\%)\end{array}$ & $\begin{array}{c}\text { Grain yield } \\
\left.(\mathrm{t} \text { ha })^{-1}\right)\end{array}$ \\
\hline Replications & 2 & 1.72 & 1.37 & 15.91 & 2.21 & 0.17 & $3867.79^{*}$ & 3.13 & $1.68^{* *}$ \\
Treatments & 17 & $22.78^{* *}$ & $4.46^{* *}$ & $81.18^{* *}$ & $2.68^{* *}$ & $73.46^{* *}$ & $8751.33^{* *}$ & $5.96^{*}$ & $1.45^{* *}$ \\
Error & 34 & 0.96 & 0.56 & 9.63 & 0.71 & 1.23 & 936.89 & 0.23 & 2.95 \\
\hline
\end{tabular}

*Significant at 0.05 level; ${ }^{* *}$ at 0.01 level

\begin{tabular}{lcccccccc}
\hline \multicolumn{2}{l}{ Table 3: Mean values of 8 characters for 18 rice genotypes } & & & & & \\
\hline Genotype & $\begin{array}{c}\text { Days to 50\% } \\
\text { flowering }\end{array}$ & $\begin{array}{c}\text { Effective bearing } \\
\text { tillers plant }{ }^{-1}\end{array}$ & $\begin{array}{c}\text { Plant height } \\
(\mathrm{cm})\end{array}$ & $\begin{array}{c}\text { Panicle } \\
\text { length }(\mathrm{cm})\end{array}$ & $\begin{array}{c}1000 \text { grain } \\
\text { weight }(\mathrm{g})\end{array}$ & $\begin{array}{c}\text { Number } \\
\text { of grains } \\
\text { Panicle }^{-1}\end{array}$ & $\begin{array}{c}\text { Percent } \\
\text { of galls } \\
(\%)\end{array}$ & $\begin{array}{c}\text { Grain } \\
\text { yield } \\
\left(\mathrm{t} \mathrm{ha}^{-1}\right)\end{array}$ \\
\hline JGL 19607 & 98.67 & 7.47 & 111.27 & 25.33 & 14.77 & 247.00 & 0.00 & 9.89 \\
JGL 20122 & 92.67 & 9.03 & 112.13 & 24.60 & 23.23 & 120.33 & 0.00 & 9.45 \\
JGL 20668 & 92.67 & 9.03 & 107.80 & 25.13 & 13.57 & 194.67 & 0.70 & 7.53 \\
JGL 20776 & 95.00 & 8.37 & 113.27 & 25.20 & 23.03 & 187.33 & 0.70 & 9.50 \\
JGL 20777 & 96.67 & 8.63 & 105.07 & 25.40 & 21.20 & 154.00 & 0.00 & 9.39 \\
JGL 21002 & 91.67 & 9.47 & 107.47 & 23.60 & 27.33 & 108.33 & 1.23 & 10.26 \\
JGL 21005 & 90.00 & 10.37 & 101.07 & 24.07 & 25.13 & 92.33 & 2.80 & 9.26 \\
JGL 21078 & 94.00 & 10.93 & 107.87 & 25.80 & 21.13 & 122.33 & 1.80 & 10.11 \\
JGL 21794 & 89.67 & 8.40 & 100.87 & 24.93 & 20.27 & 170.00 & 0.00 & 8.40 \\
JGL 21820 & 93.67 & 6.80 & 115.40 & 23.93 & 15.07 & 285.67 & 0.00 & 9.56 \\
JGL 21828 & 94.00 & 8.77 & 109.33 & 24.93 & 14.13 & 218.67 & 0.30 & 9.09 \\
JGL 21851 & 92.67 & 7.23 & 106.80 & 26.87 & 18.70 & 214.33 & 0.00 & 9.21 \\
JGL 21868 & 92.00 & 9.80 & 108.80 & 24.60 & 23.27 & 114.00 & 1.33 & 9.13 \\
JGL 21883 & 92.67 & 7.33 & 101.53 & 25.73 & 21.77 & 138.00 & 5.20 & 9.66 \\
JGL 23745 & 94.67 & 8.50 & 102.87 & 26.27 & 30.83 & 120.67 & 0.40 & 8.46 \\
JGL 3844 & 99.67 & 8.30 & 104.53 & 24.27 & 15.50 & 194.00 & 1.90 & 9.17 \\
JGL 11118 & 94.00 & 7.97 & 101.20 & 23.80 & 16.53 & 194.67 & 1.43 & 8.09 \\
JGL 18047 & 89.67 & 11.03 & 95.07 & 23.40 & 25.23 & 118.33 & 3.13 & 8.98 \\
Mean & 93.56 & 8.75 & 106.24 & 24.88 & 20.59 & 166.37 & 1.16 & 9.17 \\
C.V. & 1.05 & 8.53 & 2.92 & 3.38 & 5.38 & 18.40 & 147.62 & 5.22 \\
SEm \pm & 0.57 & 0.43 & 1.79 & 0.49 & 0.64 & 17.67 & 0.99 & 0.28 \\
CD $(p=0.05)$ & 1.62 & 1.24 & 5.15 & 1.39 & 1.84 & 50.79 & 2.85 & 0.79 \\
\hline
\end{tabular}


Percent of galls (5.20) was exhibited by JGL 21883 and the genotypes JGL 19607, JGL 20122, JGL 20777, JGJ 21794, JGL 21820 and JGL 21851 were characterized by zero percent of galls. Maximum grain yield was observed for JGL 21002 (10.26 $\mathrm{t} \mathrm{ha}^{-1}$ ) followed by JGL 21078 (10.11 $\left.\mathrm{tha}^{-1}\right)$, whereas, low yield (7.53 tha-1) was observed for JGL 20668. The extent variability with respect to studied quantitative characters was measured in terms of mean, range, PCV, GCV, heritability and genetic advance (Table 4). Higher PCV values than GCV indicating the role of environmental forces in the inheritance of these traits. Similar findings were earlier reported by Vanisree et al. (2013); Ketan and Sarkar. (2014). Higher PCV and GCV values were observed for percentage of galls followed by number of grains panicle ${ }^{-1}$ and 1000 grain weight which could be improved through selection in desirable direction, whereas, moderate values for effective bearing tillers plant ${ }^{-1}$ and low values for days to $50 \%$ flowering, plant height, panicle length and grain yield indicating less variability among genotypes for these traits. These results are in agreement with findings of Mohan et al. (2015); Toshimenla and Sapu (2013). All the characters except percent of galls exhibited small difference between PCV and GCV indicated the presence of high genetic variability and less interference of environment on expression of these traits which may facilitate selection (Yadav, 2000), whereas, in case of percent of galls more difference indicated susceptibility of this trait to environmental fluctuations. These findings are similar to earlier reports of Mohan et al. (2015); Das (2015); Ketan and Sarkar (2014); Vanisree et al. (2013); Babu et al. (2012).

Heritability indicates the extent to which a trait is transmitted to its progeny. High heritability estimates were recorded for all characters studied indicated that these traits could be improved through selection based on their phenotype except for percentage of galls and panicle length which exhibited low and moderate levels of heritable estimates, respectively. These results are similar to findings of Ramanjaneyulu et al. (2014) for 1000 grain weight and grain yield, Mohan et al. (2015) for days to 50\% flowering, Fukrei et al. (2011) for plant height and effective bearing tillers and Das (2015) for panicle length and number of grains panicle ${ }^{-1}$. Selection of best genotypes based on both heritable estimates and genetic advance values is more reliable than selecting based on heritable values alone, because observed variation in a population is due to both factors i.e., genetics and environmental whereas, genetic variability is the only heritable in nature so the heritability alone does not give an idea about the expected gain in the next generation therefore it has to be considered in combination with the genetic advance. The characters those exhibit maximum heritability and high genetic advance as percentage of mean could be used as powerful tool in selection process, such characters are controlled by the additive genes and less influenced by the environment (Panes and Sukhatme, 1995). In the present study, high heritability estimates coupled with high genetic advance values were observed for effective bearing tillers plant $^{-1}, 1000$ grain weight and number of grains panicle ${ }^{-1}$ which indicated that these traits were predominantly governed by the additive genes which could be improved through simple selection procedures. Similar results were reported by Fukrei et al. (2011) for effective bearing tillers plant ${ }^{-1}$, Toshimenla and Sapu (2013) for 1000 grain weight and Babu et al. (2012) for number of grains panicle ${ }^{-1}$. High heritability and low values of genetic advance were recorded for days to $50 \%$ flowering and plant height, whereas, panicle length exhibited moderate levels of heritability estimates and low genetic advance value indicating that these traits are under control of non-additive genes and improvement of these traits through mere selection is not useful, therefore, breeder should go for heterosis breeding and recurrent selection methods for improvement of these characters. These results are in conformity with the findings of Vanisree et al. (2013); Ketan and Sarkar (2014). Even though rice is a strictly self pollinated crop, many researchers

Table 4: Genetic parameters for yield and yield contributing traits in rice

\begin{tabular}{|c|c|c|c|c|c|c|c|}
\hline \multirow[t]{2}{*}{ Character } & \multirow[t]{2}{*}{ Mean } & \multicolumn{2}{|c|}{ Range } & \multirow[t]{2}{*}{ GCV } & \multirow[t]{2}{*}{$\mathrm{PCV}$} & \multirow{2}{*}{$\begin{array}{c}\mathrm{h}^{2} \\
\text { (Broad sense) }\end{array}$} & \multirow{2}{*}{$\begin{array}{c}\text { GA in } \% \text { over } \\
\text { mean }\end{array}$} \\
\hline & & $\min$ & $\max$ & & & & \\
\hline Days to $50 \%$ flowering & 93.56 & 89.67 & 99.67 & 2.88 & 3.07 & 88.40 & 5.58 \\
\hline Effective bearing tillers plant ${ }^{-1}$ & 8.75 & 6.80 & 11.03 & 13.05 & 15.59 & 70.10 & 22.50 \\
\hline Plant height $(\mathrm{cm})$ & 106.24 & 95.07 & 115.40 & 4.60 & 5.45 & 71.20 & 7.99 \\
\hline Panicle length (cm) & 24.88 & 23.40 & 26.87 & 3.26 & 4.69 & 48.20 & 4.66 \\
\hline 1000 grain weight $(\mathrm{g})$ & 20.59 & 13.57 & 30.83 & 23.83 & 24.43 & 95.20 & 47.88 \\
\hline Number of grains panicle ${ }^{-1}$ & 166.37 & 92.33 & 285.67 & 30.68 & 35.77 & 73.50 & 54.20 \\
\hline Percent of galls (\%) & 1.16 & 0.00 & 5.20 & 86.20 & 170.95 & 25.40 & 89.55 \\
\hline Grain yield $\left(\mathrm{t} \mathrm{ha}^{-1}\right)$ & 9.17 & 7.53 & 10.26 & 6.97 & 8.70 & 64.10 & 11.49 \\
\hline
\end{tabular}


(Ramiah and Ramaswamy, 1941 and Oka, 1957) confirmed the occurrence of heterosis and many of the released hybrid rice varieties have shown $15-20 \%$ higher yield potential than the best inbred variety grown under similar conditions. Availability of CGMS system in rice could enable the breeders for commercial exploitation of heterosis through development of new male sterile and potential restorer lines. As several reports indicated the decreasing of genetic gains obtained by different breeding methods around the world, there is an urgent need to improve the populations. However, recurrent selection is not a common breeding methodology choice in rice which is a self pollinated crop, Fujimaki (1979) suggested its application in rice for increases the frequencies of favorable alleles using male sterility. Grain yield recorded high heritability and moderate genetic advance indicated the role of both additive and non-additive genes in inheritance of this complex trait, these results are similar to findings of Ketan and Sarkar (2014). The trait percent of galls expressed moderate heritability and high genetic advance which indicated the predominance of additive genes in governing the inheritance of this trait and selection based on phenotype could be done in the negative direction to eliminate or reduce the trait in successive breeding populations. Mohan et al. (2015) through his findings reported that as gall midge resistance is a qualitative trait, selection for such character is easier in negative direction.

Eighteen genotypes were grouped into three clusters (Table 5) of which cluster I was the largest comprising of 14 genotypes followed by cluster II and III comprising 3 and 1 genotypes each respectively. Intra and inter cluster distance values (Table 6) revealed zero intra cluster distance values for cluster III. Ramanjaneyulu et al. (2014) stated that unidirectional selection practices in the past may results in uniform features with less divergence among the genotypes of similar cluster with low intra cluster distance, whereas, considerable level of intra cluster distance in clusters I and II indicated that genotypes from these clusters could be selected based on highest mean values for desirable traits. It was reported that genotypes within the cluster with high degree of divergence would produce more desirable breeding material for achieving maximum genetic advance. From the inter cluster distancevalues it was clear that highest divergence occurred between cluster II and III (10.48) followed by cluster I and III (7.49) and cluster I and II (6.34) indicating the presence of greater diversity between genotypes of these groups. Hence, crossing between genotypes belonging to these clusters may result in high heterosis, which could be exploited in crop improvement. Crosses involving parents belonging to most divergent clusters would be expected to manifest maximum heterosis and wide variability of genetic architecture (Soroush et al.,2004). Considerable amount of variation among the cluster means (Table 7). was observed for number of grains panicle ${ }^{-1}$ and 1000 grain weight compared to other traits studied indicating the presence of ample diversity for these trait in experimental material. Genotypes of cluster I were characterized by early in flowering but more incidence of galls, whereas, cluster II genotypes recorded more number of grains panicle ${ }^{-1}$ and low 1000 grain weight, on the contrary, cluster III genotype was characterized by more 1000 grain weight and less number of grains panicle ${ }^{-1}$. Therefore, genotypes from clusters II and III

\begin{tabular}{lcl}
\hline $\begin{array}{l}\text { Table 5: Distribution of 18 rice genotypes in different clusters } \\
\text { Cluster } \\
\text { no. }\end{array}$ & $\begin{array}{c}\text { No. of } \\
\text { genotype }\end{array}$ & Genotypes \\
\hline I & 14 & JGL 20122, JGL 20668, JGL 20776, \\
& & JGL 20777, JGL 21002, JGL 21005, \\
& & JGL 21078, JGL 21794, JGL 21828, \\
& & JGL 21851, JGL 21868, JGL 21883, \\
II & 3 & JGL 11118, JGL 18047 \\
III & 1 & JGL 19607, JGL 21820, JGL 3844 23745 \\
\hline
\end{tabular}

Table 6: Average intra (diagonal) and inter cluster distances (Tocher method) for 18 rice genotypes

\begin{tabular}{lccc}
\hline Clusters & Cluster I & Cluster II & Cluster III \\
\hline Cluster I & 4.6 & 6.34 & 7.49 \\
Cluster II & & 4.22 & 10.48 \\
Cluster III & & & 0 \\
\hline
\end{tabular}

Table 7: Cluster means and percent contribution of each character towards total divergence of 18 rice genotypes for 8 characters

\begin{tabular}{lcccccccc}
\hline Cluster & $\begin{array}{c}\text { Days to } \\
50 \% \\
\text { flowering }\end{array}$ & $\begin{array}{c}\text { Effective } \\
\text { bearing } \\
\text { tillers Plant }^{-1}\end{array}$ & $\begin{array}{c}\text { Plant } \\
\text { height }(\mathrm{cm})\end{array}$ & $\begin{array}{c}\text { Panicle } \\
\text { length } \\
(\mathrm{cm})\end{array}$ & $\begin{array}{c}1000 \\
\text { grain } \\
\text { weight }(\mathrm{g})\end{array}$ & $\begin{array}{c}\text { Number } \\
\text { of grains } \\
\text { Panicle }^{-1}\end{array}$ & $\begin{array}{c}\text { Percent } \\
\text { of galls } \\
(\%)\end{array}$ & $\begin{array}{c}\text { Grain } \\
\text { yield } \\
\left(\mathrm{t} \mathrm{ha}^{-1}\right)\end{array}$ \\
\hline Cluster I & 92.67 & 9.03 & 105.59 & 24.6 & 21.04 & 153.38 & 1.33 & 9.15 \\
Cluster II & 97.33 & 7.52 & 110.4 & 24.51 & 15.11. & 242.22 & 0.63 & 9.54 \\
Cluster III & 94.67 & 8.5 & 102.87 & 26.27 & 30.83 & 120.67 & 0.4 & 8.46 \\
\% Contribution of character & 21.57 & 3.27 & 7.84 & 1.31 & 53.59 & 1.31 & 5.23 & 5.88 \\
Number of times ranked first & 33 & 5 & 12 & 2 & 82 & 2 & 8 & 9 \\
\hline
\end{tabular}


could be selected to develop fine grain and bold grain varieties, respectively and genotypes from cluster I could be selected for developing the early genotypes. With regard to gall midge resistance, genotypes from cluster II and III which recorded least cluster means for percent of galls could be used in the breeding programme for obtaining segregants with resistant to gall midge. Similar findings were reported by Mohan et al. (2015). The percent contribution of each trait (Table 7) towards total divergence showed that 1000 grain weight and days to $50 \%$ flowering contributed maximum suggesting that these traits may be useful for selecting the most diverse lines in segregating populations, whereas, remaining traits contributed least towards divergence which are of less importance in selection of diverse parents. Similar results were reported by Sabesan et al. (2009) for days to 50\% flowering, Banumathy et al. (2010) for plant height and effective bearing tillers, Garg et al. (2011) for panicle length and number of grains planicle ${ }^{-1}$ and Kumar et al. (2014); Mohan et al. (2015) for 1000 grain weight, grain yield and percent of galls. As, 1000 grain weight and days to $50 \%$ flowering exhibited more contribution to the divergence, the present experimental material could be used for developing rice varieties with desirable grain types and maturity durations.

\section{Conclusion}

Genotypes from clusters II and III could be used in breeding programme to produce desirable transgressive segregants. The genotype JGL 23745 was identified as a potential source for developing gall midge tolerant lines, and the present experimental material could be used for deriving the lines of different maturity groups and grain types. Heterosis could be exploited through development of new male sterile lines and potential restorers with the use of available cytoplasmic genetic male sterile sources, further, recurrent selection could be practiced to avoid further narrowing down of genetic base in rice germplasm.

\section{Acknowledgement}

The author sincerely thanks Rice Research Scheme, Regional Agricultural Research Station, Jagtial where the work has been done and also Associate Director of Research, RARS, Jagtial for providing the support.

\section{References}

Allard, R.W., 1960. Principles of plant breeding. Publishers by John Wiley and Sons Inc. New York USA, 485.

Babu, R.V., Shreya, K., Kuldeep Singh Dangi, Usharani, G., Nagesh, P., 2012. Genetic variability studies for qualitative and quantitative traits in popular rice (Oryza sativa L.) hybrids of India. International Journal of
Scientific and Research Publications 2(6), 1-5.

Banumathy, S., Manimaran, R., Sheeba, A., Manivannan, N., Ramya, B., Kumar, D., Ramasubramanian, G.V., 2010. Genetic diversity analysis of rice germplasm lines for yield attributing traits. Electronic Journal of Plant Breeding 1(4), 500-504.

Bentur, J.S., Pasalu, I.C., Sarma, N.P., Rao, U.P., Mishra, B., 2003. Gall midge resistance in rice. DRR Research paper Series 01/2003. Directorate of Rice Research, Hyderabad, India, 20.

Bose, L.K., Pradhan, S.K., 2005. Genetic divergence in deepwater rice genotypes. Journal of central European agriculture 6(4), 635-640.

Burton, G.W., 1952. Quantitative inheritance in grasses. Proceeding of sixth International Congress, 277-283.

Das, S., 2015. Genetic studies of yield variation in mid duration irrigated rice. Journal of Agriculture and Veterinary Science 8(4), 41-43.

Falconer, D.S., 1981. Introduction to quantitative genetics. Oliver and Boyd, London, 340.

Fujimaki, H.,1979. Recurrent selection by using male sterility for rice improvement. Japan Agricultural Research Quarterly (13), 153-156.

Fukrei, K.P., Kumar, A., Tyagi, W., Rai, M., Pattanayak, A., 2011. Genetic variability in yield and its components in upland rice grown in acid soils of North East India. Journal of Rice Research 4(1\&2), 4-7.

Garg, P., Pandey, D.P., Kaushik, R.P., 2011. Genetic divergence for yield and quality traits in rice (Oryza sativa L.). Journal of Rice Research 4(1\&2), 1-5.

Henrichs, E.A., Pathak, P.K., 1981. Resistance to the rice gall midge Orseolia oryzae in rice. International Journal of Tropical Insect Science (2), 123-132.

IRRI., 2002. Standard Evaluation System for Rice, International Rice Research Institute, Los Baños, Philippine.

Ketan, R., Sarkar, G., 2014. Studies on variability, heritability, genetic advance and path analysis in some indigenous Aman rice (Oryza sativa L.). Journal of Crop and Weed 10(2), 308-315.

Krishnaiah, K., Varma, N.R.G., 2011. Changing insect pest scenario in the rice ecosystem-A National perspective, Rice Knowledge Management Portal, DRR, Hyderabad.

Kumar, B., Gupta, B.B., Bikram Singh., 2014. Genetic diversity for morphological and quality traits in rice (Oryzae sativa L). The Bioscan 9(4), 1759-1762.

Kumbhar, S.D., Kulwal, P.L., Patil, J.V., Sarawate, C.D., Gaikwad, A.P., Jadhav, A.S., 2015. Genetic diversity and population structure in land races and improved rice varieties from India. Rice Science 22(3), 99-107.

Lingaraj, V.K., Chakravarthy, A.K., Eregowda, T.N., 2008. 
Detection of Asian rice gall midge (Orseolia oryzae) biotype 1 in the new locations of Karnataka, South India. Bulletin of Insectology 61(2), 277-281.

Mahalanobis, P.C., 1936. On the generalized distance in statistics. In: Proceedings of the National Institute of Sciences of India (2), 49-55.

Miller, P.A., Williams, C., Roginson, H.F., Comstock, R.E., 1958. Estimates of genotypic and environmental variance and covariance and implication in section. Agronomy Journal (50), 126-131.

Mohan, Y.C., Thippeswamy, S., Bhoomeshwar, K., Madhavilatha, B., Jameema Samreen., 2015. Diversity analysis for yield and gall midge resistance in rice (Oryza sativa L.) in northern telangana zone, India. SABRAO Journal of Breeding and Genetics 47(2), 160-171.

Murthy, A., Arunachalan, V., 1966. The nature of genetic divergence in relation to breeding system in crop plants. Indian Journal of Genetics and Plant Breeding (26), 188-198.

Oka, H.I., 1957. Genetic analysis for the sterility of hybrids between distantly related varieties of cultivated rice. Journal of Genetics (55), 397-409.

Panes, V.G., Sukhatme, P.V., 1995. Statistical methods for agricultural workers, $3^{\text {rd }}$ edition ICAR, New Delhi, 58.

Panse, V.G., Sukhatme, P.V., 1985. Statistical methods for agricultural workers, $2^{\text {nd }}$ edition ICAR, New Delhi, 361.

Ramanjaneyulu, A.V., Gouri Shankar, V., Neelima, T.L., Shashibhushan, D., 2014. Genetic analysis of rice (Oryza sativa L.) genotypes under aerobic conditions on alfisols. SABRAO Journal of Breeding and Genetics 46(1), 99-111.

Ramiah, K., Ramaswamy, K., 1941. Hybrid vigor in rice
(Oryza sativa L.), Indian Journal of Genetics and Plant Breeding 1, 4-12.

Ramya, K., Kumar, S.K., 2008. Genetic divergence in rice. Crop Improvement 35(2), 119-121.

Rao, C.R., 1952. Advance Statistical Methods in Biometrical Research. John Wiley and Sons, New York.

Roy, A., Panwar, D.V.S., 1993. Genetic divergence in rice. Oryza 30, 197-201.

Sabesan, T., Saravanan, K., Anandan, A., 2009. Genetic divergence analysis for certain yield and quality traits in rice (Oryza sativa L.) grown in irrigated saline low land of Annamalainagar, South India. Journal of Central European Agriculture 10(4), 405-410.

Soroush, H.R., Mesbah, M., Hosseinzadeh, Pour, R.B., 2004. Genetic and phenotypic variability and cluster analysis for quantitative and qualitative traits of rice. Seed and Plant Improvement Journal 20(2), 167-182.

Toshimenla, Changkija, S., 2013. Genetic variability in yields and its component characters in upland rice of Nagaland. Indian Journal of Hill Farming 26(2), 84-87.

Vanisree, S., Swapna, K., Raju, Ch. D., Raju, Ch. S., Sreedhar, M., 2013. Genetic variability and selection criteria in rice. Journal of Biological and Scientific Opinion 1(4), 342-346.

Yadav, R.K., 2000. Studies on genetic variability for some quantitative characters in rice (Oryza sativa L.). Advances in Agricultural Research in India (13), 205-207.

Yaqoob, M., Hussain, N., Rashid, A., 2012. Assessment of genetic variability in rice (Oryza sativa L.) genotypes under rainfed conditions. Journal of Agricultural Research 50(3), 311-320. 